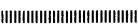

論文

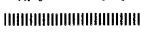

\title{
エトリンガイトの生成に及ぼすグルコン酸ナトリウムの影響
}

\author{
露木尚光・岡 龍一郎 ${ }^{\dagger}$ 宮川継男 ・笠井順一* \\ (日本大学理工学部一般化学科, 274 船橋市習志野台 7-24-1 \\ *日本大学生産工学部工業化学科, 275 習志野市泉町 1-2-1
}

\section{Effects of Sodium Gluconate on the Formation of Ettringite}

\author{
Naomitsu TSUYUKI, Ryuichiro OKA ${ }^{\dagger}$, Tsugio MIYAKAWA and Junichi KASAI* \\ Department of Chemistry, College of Science and Technology, Nihon University, \\ 7-24-1, Narashinodai, Funabashi-shi 274 \\ * Department of Industrial Chemistry, College of Industrial Technology, Nihon University, \\ 1-2-1, Izumi-cho, Narashino-shi 275
}

The initial setting time of portland cement containing sodium gluconate is quickly than that of cement reithout sodium gluconate. Such a behavior of early hydration is due to an action of the formation of ettringite. The formation process of ettringite from hydration of synthesized $\mathrm{C}_{3} \mathrm{~A}$ and $\mathrm{CaSO}_{4} \cdot 2 \mathrm{H}_{2} \mathrm{O}$ with the addition of sodium gluconate was investigated from the changes in composition of liquid phase within several minutes with standing time. The results are summarized as follows. Calcium and sulfate contents in liquid phase increase by the addition of sodium gluconate, and the solubility of $\mathrm{CaSO}_{4} \cdot 2 \mathrm{H}_{2} \mathrm{O}$ is also enlarged. The time shown high concentration of calcium and sulfate contents is longer than that without additives. It is resulted to form $\mathrm{Ca}$ complex with gluconic acid and $\mathrm{Ca}^{2+}$ in liquid phase. Ettringite was produced in this period and unreacted $\mathrm{CaSO}_{4} \cdot 2 \mathrm{H}_{2} \mathrm{O}$ was disappered. The concentration of calcium content in liquid phase immediately increased after contact with water, and decreased after their. That is, the phenomenon of deposition happens rapidly after the dissolution. After the formation of $\mathrm{Ca}$ complex, gluconic acid was adsorbed on the surface of unhydrated particles. CaSO $\mathrm{O}_{4} \cdot 2 \mathrm{H}_{2} \mathrm{O}$ depressed the adsorption of gluconic acid on $C_{3} A$.

[Received June 29, 1989 ; Accepted January 25, 1990]

Key-words : Tricalcium aluminate, Sodium gluconate, Ettringite, Monosulfate, Organic admixture, Setting retarder

\section{1. 緒 言}

ポルトランドセメントの水和を支配する初期の挙動に ついては多くの報告がある。添加した $\mathrm{CaSO}_{4} \cdot 2 \mathrm{H}_{2} \mathrm{O}$ に よる凝結の遅延作用は，工トリンガイト(3 $\left.\mathrm{CaO} \cdot \mathrm{Al}_{2} \mathrm{O}_{3} \cdot 3 \mathrm{CaSO}_{4} \cdot 32 \mathrm{H}_{2} \mathrm{O}\right)$ の被膜形成に起因すると 考えられている. しかし, Locher ら"の研究によると, 水和反応の遅延と凝結の遅延との間には直接的な関係は なく, 少なくともエトリンガイトの被膜は水和反応の遅 延原因とは考えられないとしている。著者らは, $\mathrm{CaSO}_{4} \cdot 2 \mathrm{H}_{2} \mathrm{O}$ と $\mathrm{Ca}(\mathrm{OH})_{2}$ とが共存すると，水和反応が 非常に長く停止することを明らかにしてその水和モデル を提案した2).

ポルトランドセメントはモルタルやコンクリートとし て使用されるが，実際にはこれに有機混和剤を併用する 場合がほとんどである．有機混和剤を含むポルトランド

\footnotetext{
現在：山宗化学 (株) 技術部，254 神奈川県平塚市東八幡 $3-6-22$

Now with Technical Division, Yamaso Chemical Co., Ltd., 3-6-22, Higashihachiman, Hiratsuka-shi, Kanagawa 254
}

セメントペーストの凝結遅延機構について, 総括的に論

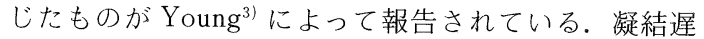
延剤としてグルコン酸ナトリウムのようなアニオン系界 面活性剂を用いた $1: 2$ モルタルの凝結の始発時間は, プレーンのときと比較するとむしろ速まることがしばし ば起こる，この原因についてはいまだに解決できていな い.

著者らはこのような現象を示す原因が接水直後の液相 の挙動にあると考え, 数分以内の液相の経時変化を明ら かにすることを目的とした．本研究では， $3 \mathrm{CaO} \cdot \mathrm{Al}_{2} \mathrm{O}_{3}$

(以下 $\mathrm{C}_{3} \mathrm{~A}$ と記す) を合成し，エトリンガイト生成時 におけるグルコン酸ナトリウム添加の作用を液相の挙動 から検討した。

\section{2. 実 験}

\section{1 実験試料}

$\mathrm{C}_{3} \mathrm{~A}$ の合成では，著者らは和光純薬工業製のアルカ リ分析用 $\mathrm{CaCO}_{3}$, 特級 $\alpha-\mathrm{Al}_{2} \mathrm{O}_{3}$ を使用し,これを $3: 1$ のモル比に配合してボールミルで 1 時間均一に混合し 
た.これを $1000^{\circ} \mathrm{C} て ゙ 4$ 時間仮焼成した後, 200 メッシュ 以下に粉砕し, 加圧成形してペレットを作り, $1450^{\circ} \mathrm{C}$ で 4 時間焼成した。この操作を 2 回繰り返したものを徐 冷して粉砕し, 200 メッシュ通過のものを実験に供した. なお，この試料は粉末 $\mathrm{X}$ 線回折 $(\mathrm{XRD})$ によって $\mathrm{C}_{3} \mathrm{~A}$ 相だけであることを確認した。また， $\mathrm{CaSO}_{4} \cdot 2 \mathrm{H}_{2} \mathrm{O}$ は 同社製の特級,グルコン酸ナトリウムは化学用を用いた.

\section{2 実験方法}

\section{2 .1 凝結時間}

普通ポルトランドセメントにグルコン酸ナトリウムを 添加した 1：2 モルタルの凝結時間をJIS A 6204 に準拠 して測定した.

\subsection{2 水和発熱速度}

$\mathrm{C}_{3} \mathrm{~A}$ 単味の場合, それにグルコン酸ナトリウムを添 加した場合，また $\mathrm{C}_{3} \mathrm{~A} に$ 対して $\mathrm{CaSO}_{4} \cdot 2 \mathrm{H}_{2} \mathrm{O} 20 \mathrm{wt} \%$ 混合した場合とそれにグルコン酸ナトリウムを添加した 場合の水和発熱速度を双子型伝導微少熱量計で測定し た。水固体比はすべて 5 である.

\subsection{3 液相組成}

純水又は $0.25 \mathrm{wt} \%, 0.50 \mathrm{wt} \%$ グルコン酸ナトリウ 厶溶液 $100 \mathrm{ml}$ 中に, 合成した $\mathrm{C}_{3} \mathrm{~A}$ を $2.0 \mathrm{~g}$ 分散させた サスペンションを密封し， $25^{\circ} \mathrm{C}$ のイキュベーターで 連続かくはんした。これは $\mathrm{C}_{3} \mathrm{~A}$ に対してグルコン酸ナ トリウムを $12.5 \mathrm{wt} \%, 25.0 \mathrm{wt} \%$ 添加した場合に相当 する.更に, $\mathrm{C}_{3} \mathrm{~A} 2.0 \mathrm{~g}$ に対して $\mathrm{CaSO}_{4} \cdot 2 \mathrm{H}_{2} \mathrm{O} 20 \mathrm{wt} \%$, $40 \mathrm{wt} \%$ 混合したものを分散させた場合も同様に行っ た。このような溶液を多数作り，それぞれ所定の経過時 間ごとに 17 G-4 のグラスフィルターで吸引沪過し, 液 相中に溶存する $\mathrm{Ca}$ 分, $\mathrm{Al}$ 分, 硫酸根分 (以下 $\mathrm{SO}_{3}$ 分 と記す), $\mathrm{Na}$ 分及び沪液の $\mathrm{pH}$ を測定した. $\mathrm{Ca}$ 分, $\mathrm{Al}$ 分, $\mathrm{Na}$ 分は誘導結合型発光分光分析 (ICP ESM) によっ て, $\mathrm{SO}_{3}$ 分はイオンクロマトグラフィーによって測定 した。結果はそれぞれ $\mathrm{CaO}, \mathrm{Al}_{2} \mathrm{O}_{3}, \mathrm{SO}_{3}, \mathrm{Na}$ として求 めた。

\subsection{4 吸着量の測定}

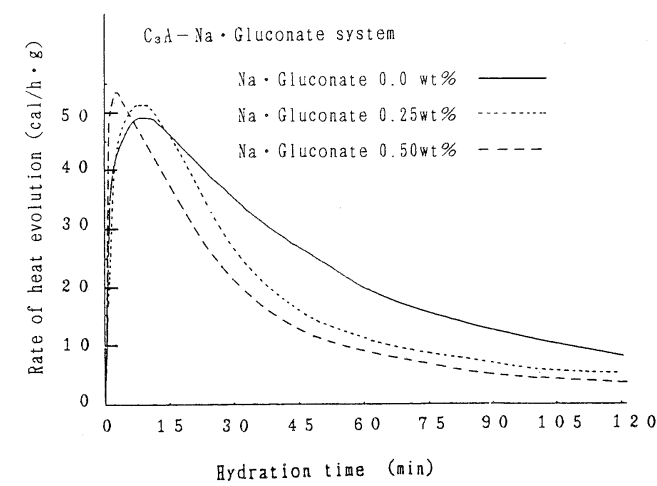

$\mathrm{C}_{3} \mathrm{~A}, \mathrm{CaSO}_{4} \cdot 2 \mathrm{H}_{2} \mathrm{O}$ などの固相に吸着されるグルコン 酸の量は, グルコン酸ナトリウムの出発濃度から液相中 に残存するグルコン酸ナトリウムの濃度の差から求め た。液相中に残存するグルコン酸ナトリウムをイオン交 換によってグルコン酸とした後，これを高速液体クロマ トグラフィーによって定量した。

\subsection{5 固相解析}

他方, 各固相はメ夕ノール, アセトンで水和を停止さ せた後,デシケーター中で乾燥した。この試料をXRD 及び走查型電子顕微鏡 $(\mathrm{SEM})$ によって解析し, 水和 時間に対応する固相の同定, 組織表面の観察を行った.

\section{3. 結 果}

\section{1 凝結時間}

2.2.1 項によって凝結の始発，終結時間を測定した結 果を表1に示す。

グルコン酸ナトリウムを添加すると, 無添加のときよ りも凝結の終結は遅れるが, 始発はむしろ速くなること が分かった。

\section{2 水和発熱速度}

$0.25 \mathrm{wt} \%, 0,50 \mathrm{wt} \%$ のグルコン酸ナトリウムを添加 したときの $\mathrm{C}_{3} \mathrm{~A}$ の水和発熱速度を2.2.2 項によって測 定した.この結果を図1に示す.

$\mathrm{CaSO}_{4} \cdot 2 \mathrm{H}_{2} \mathrm{O}$ が存在しない場合, 水和直後の 1 次ピー クはグルコン酸ナトリウム $0.50 \mathrm{wt} \%$ では少し速まる が, その後の速度は遅くなり, 総発熱量は低下する. 他 方, $\mathrm{CaSO}_{4} \cdot 2 \mathrm{H}_{2} \mathrm{O}$ が存在した場合, 1 次ピークの呈す

Table 1. The setting time of portland cement paste and mortar added $\mathrm{Na} \cdot$ Gluconate.

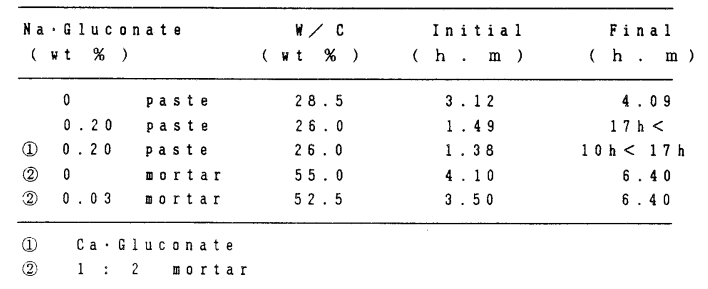

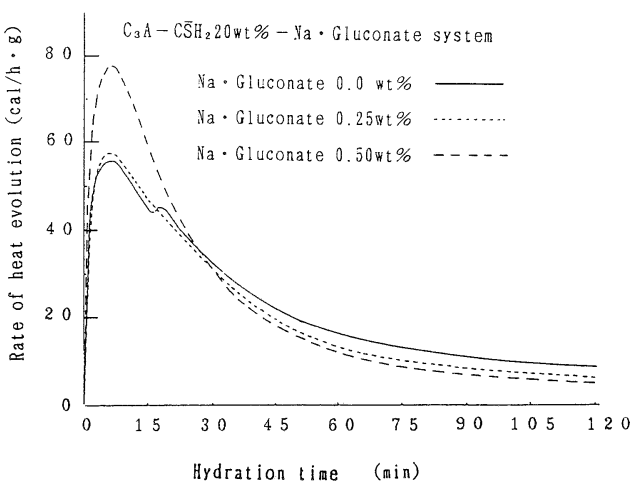

Fig. 1. The rate of heat evolution as a function of hydration time at $25^{\circ} \mathrm{C}$. 
る時間はグルコン酸ナトリウム添加によってはほよんど 影響されないが, 水和直後から 30 分までの総発熱量は, グルコン酸ナトリウムの濃度によっては増加することを 示している.

\section{3 液相組成}

2.2.3 項によって液相組成の経時変化を測定した。

（1） $0.25 \mathrm{wt} \% ， 0.50 \mathrm{wt} \%$ のグルコン酸ナトリウム 溶液中に $\mathrm{C}_{3} \mathrm{~A}$ を分散させたときの液相組成の経時変化 を図2，図3に示す。

液相中に存在する $\mathrm{Ca}$ 分, $\mathrm{Al}$ 分の量は水和時間とと もに増加する．グルコン酸ナトリウム濃度が高い 0.50 $\mathrm{wt} \%$ のとき $\mathrm{Ca}$ 分の溶存量は， $0.25 \mathrm{wt} \%$ 添加に比べ て少ない。

（2） $0.25 \mathrm{wt} \% ， 0.50 \mathrm{wt} \%$ のグルコン酸ナトリウム 溶液中に $\mathrm{C}_{3} \mathrm{~A}$ 及び $\mathrm{CaSO}_{4} \cdot 2 \mathrm{H}_{2} \mathrm{O}$ を混合したときの液相

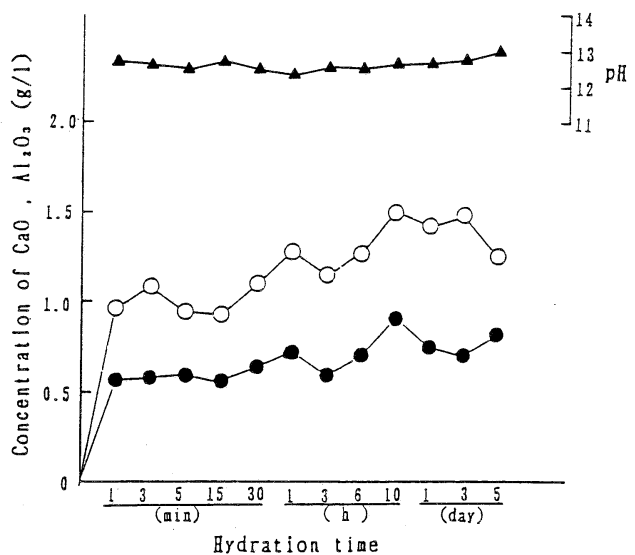

Fig. 2. The concentration of $\mathrm{CaO}(\mathrm{O}), \mathrm{Al}_{2} \mathrm{O}_{3}(\mathbf{O})$ and $\mathrm{pH}(\bullet)$ in liquid phase of $\mathrm{C}_{3} \mathrm{~A}-\mathrm{Na} \cdot$ Gluconate $0.25 \mathrm{wt} \%$ system at $25^{\circ} \mathrm{C}$.

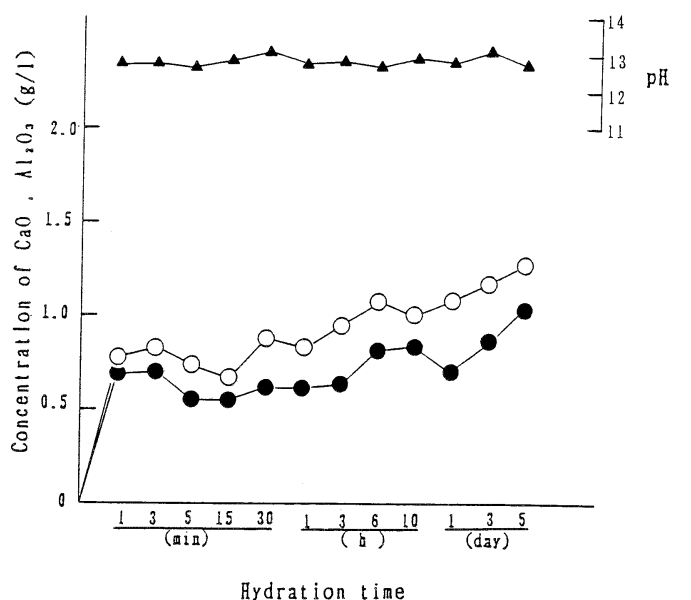

Fig. 3. The concentration of $\mathrm{CaO}(\mathrm{O}), \mathrm{Al}_{2} \mathrm{O}_{3}(\mathbf{O})$ and $\mathrm{pH}(\bullet)$ in liquid phase of $\mathrm{C}_{3} \mathrm{~A}-\mathrm{Na} \cdot$ Gluconate $0.50 \mathrm{wt} \%$ system at $25^{\circ} \mathrm{C}$.
組成の経時変化を図 4, 図 5 に示す。図 4 は $\mathrm{C}_{3} \mathrm{~A}$ に対 して $\mathrm{CaSO}_{4} \cdot 2 \mathrm{H}_{2} \mathrm{O}$ を $20 \mathrm{wt} \%$ ，図 5 は $40 \mathrm{wt} \%$ 混合した 場合である.

液相中の $\mathrm{SO}_{3}$ 分の溶存量をみると, $\mathrm{CaSO}_{4} \cdot 2 \mathrm{H}_{2} \mathrm{O}$ の 水に対する溶液度 $1.02 \mathrm{~g} \mathrm{SO}_{3} / l$ よりもグルコン酸ナト リウム溶液中では一時的に高い濃度を示し，その後急速 に減少している。また，グルコン酸ナトリウム濃度が高 くなると, $1.02 \mathrm{~g} \mathrm{SO}_{3} / l$ 以上の値を呈する時間は長く なることが分かる。

液相中の $\mathrm{Ca}$ 分の挙動をみると, 溶存量は水和直後一 時的に増加した後，減少するが，15分後からは再び増 加する傾向がある. 15 分以前の $\mathrm{Ca}$ 分の濃度増加はグ ルコン酸ナトリウム存在下の特異な現象である．純水中 に分散した場合にはそのようなことが起こらない。比較 のため，グルコン酸ナトリウム無添加の場合も同様な方

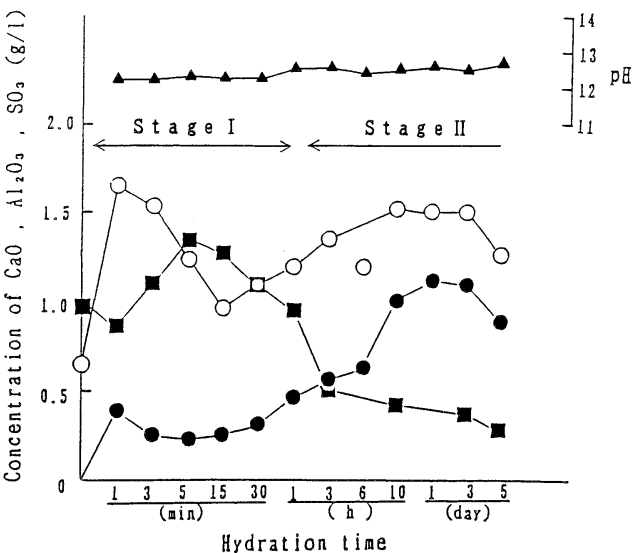

Fig. 4. The concentration of $\mathrm{CaO}(\mathrm{O}), \mathrm{Al}_{2} \mathrm{O}_{3}(-)$ $\mathrm{SO}_{3}(\square)$ and $\mathrm{pH}(\boldsymbol{\Delta})$ in liquid phase of $\mathrm{C}_{3} \mathrm{~A}-\mathrm{C} \overline{\mathrm{S}} \mathrm{H}_{2}$ $20 \mathrm{wt} \%-\mathrm{Na} \cdot \mathrm{Gluconate} 0.25 \mathrm{wt} \%$ system at $25^{\circ} \mathrm{C}$.

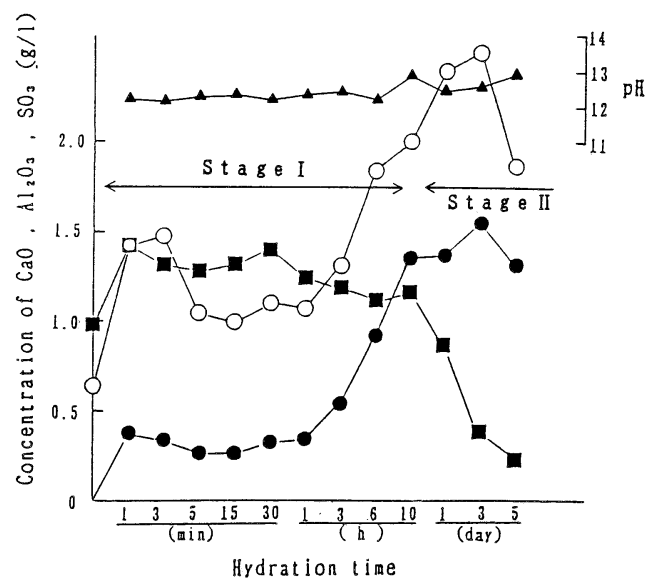

Fig.5. The concentration of $\mathrm{CaO}(\mathrm{O}), \mathrm{Al}_{2} \mathrm{O}_{3}(\mathbf{O})$, $\mathrm{SO}_{3}(\boldsymbol{\square})$ and $\mathrm{pH}(\boldsymbol{\bullet})$ in liquid phase of $\mathrm{C}_{3} \mathrm{~A}-\mathrm{C} \overline{\mathrm{S}} \mathrm{H}_{2}$ $20 \mathrm{wt} \%-\mathrm{Na} \cdot$ Gluconate $0.50 \mathrm{wt} \%$ system at $25^{\circ} \mathrm{C}$. 


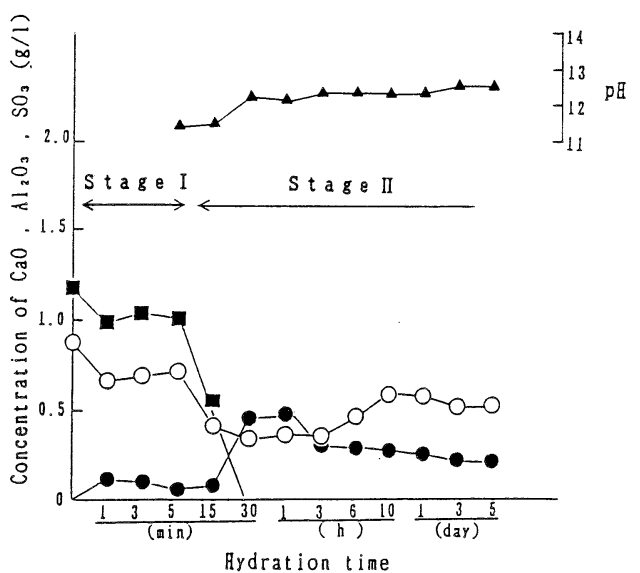

Fig. 6. The concentration of $\mathrm{CaO}(\bigcirc), \mathrm{Al}_{2} \mathrm{O}_{3}(\mathbf{O})$, $\mathrm{SO}_{3}(\square)$ and $\mathrm{pH}(\boldsymbol{\bullet})$ in liquid phase of $\mathrm{C}_{3} \mathrm{~A}-\mathrm{C}_{\overline{\mathrm{S}}} \mathrm{H}_{2}$ $20 \mathrm{wt} \%-\mathrm{H}$ system at $25^{\circ} \mathrm{C}$.

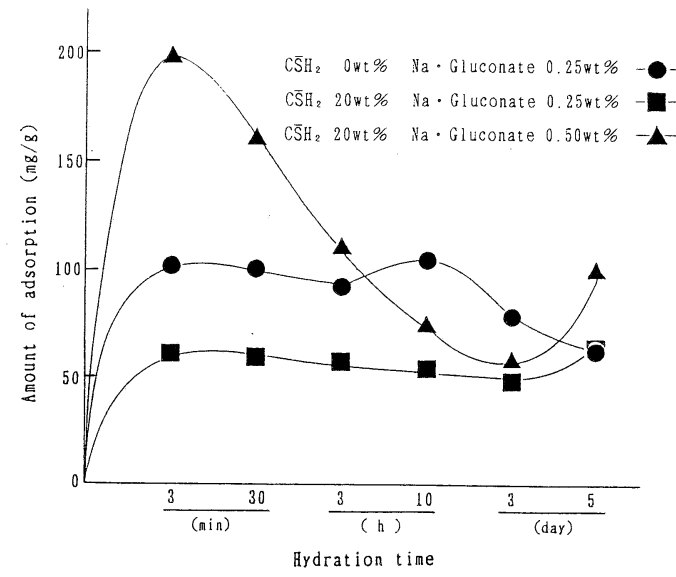

Fig. 7. The amount of adsorption of Gluconic acid against $\mathrm{C}_{3} \mathrm{~A} 1 \mathrm{~g}$ in $\mathrm{Na} \cdot$ Gluconate solution with or without $\mathrm{C} \overline{\mathrm{S}} \mathrm{H}_{2}$ at $25^{\circ} \mathrm{C}$.
法で測定した。この結果を図6に示す.

$\mathrm{Al}$ 分の挙動も $\mathrm{Ca}$ 分の挙動とほぼ同様な傾向を示し た．更に，液相中に残存するグルコン酸ナトリウムの濃 度から, 固相に吸着されたグルコン酸の量を水和時間ご とに求めた.この結果を図7に示す.

$\mathrm{CaSO}_{4} \cdot 2 \mathrm{H}_{2} \mathrm{O}$ の有無によってグルコン酸の吸着量は 異なる. 同濃度のグルコン酸ナトリウム溶液中では, $\mathrm{CaSO}_{4} \cdot 2 \mathrm{H}_{2} \mathrm{O}$ が共存すると吸着量は減少することが分 かった。 また，同様に液相中の残存 $\mathrm{Na}$ 分の量から，固 相に吸着される $\mathrm{Na}$ 分の量を測定した。この結果を図 8 に示す.

$\mathrm{CaSO}_{4} \cdot 2 \mathrm{H}_{2} \mathrm{O}$ の有無にかかわらず, $\mathrm{Na}$ 分の一部は吸 着されることが分かった。

\section{4 固相解析}

2.2 .5 項によって生成物の経時変化を求めた。 $\mathrm{CaSO}_{4} \cdot 2 \mathrm{H}_{2} \mathrm{O}$ が存在しない図 2 に対応する固相の経時

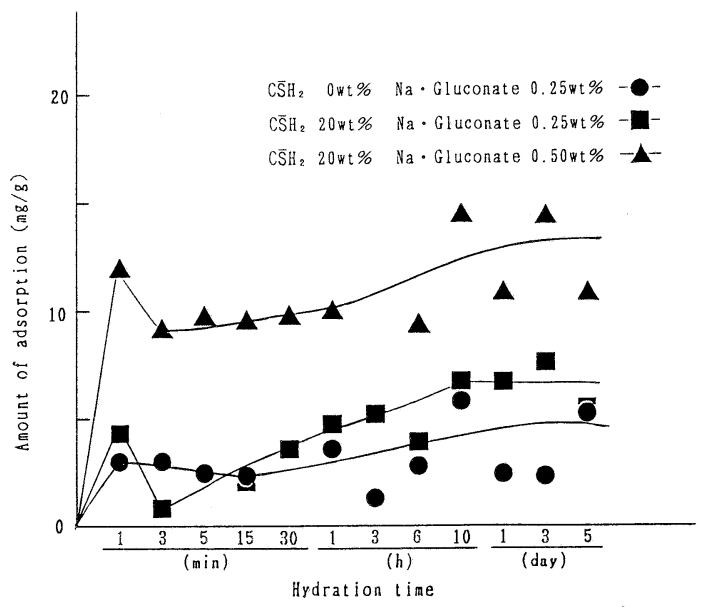

Fig. 8. The amount of adsorption of $\mathrm{Na}$ against $\mathrm{C}_{3} \mathrm{~A} 1 \mathrm{~g}$ in $\mathrm{Na} \cdot$ Gluconate solution with or without $\mathrm{CS}_{2}$ at $25^{\circ} \mathrm{C}$.
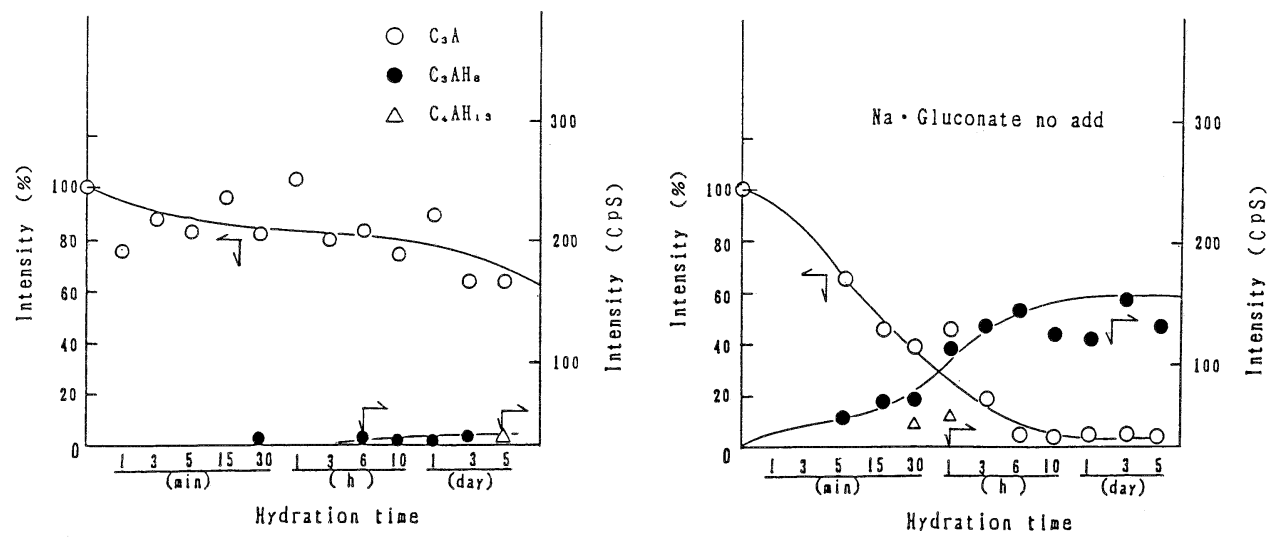

Fig. 9. The amounts of solid phase measured by XRD of $\mathrm{C}_{3} \mathrm{~A}-\mathrm{Na} \cdot$ Gluconate $0.25 \mathrm{wt} \%$ system and without Gluconate system by various hydration time. 

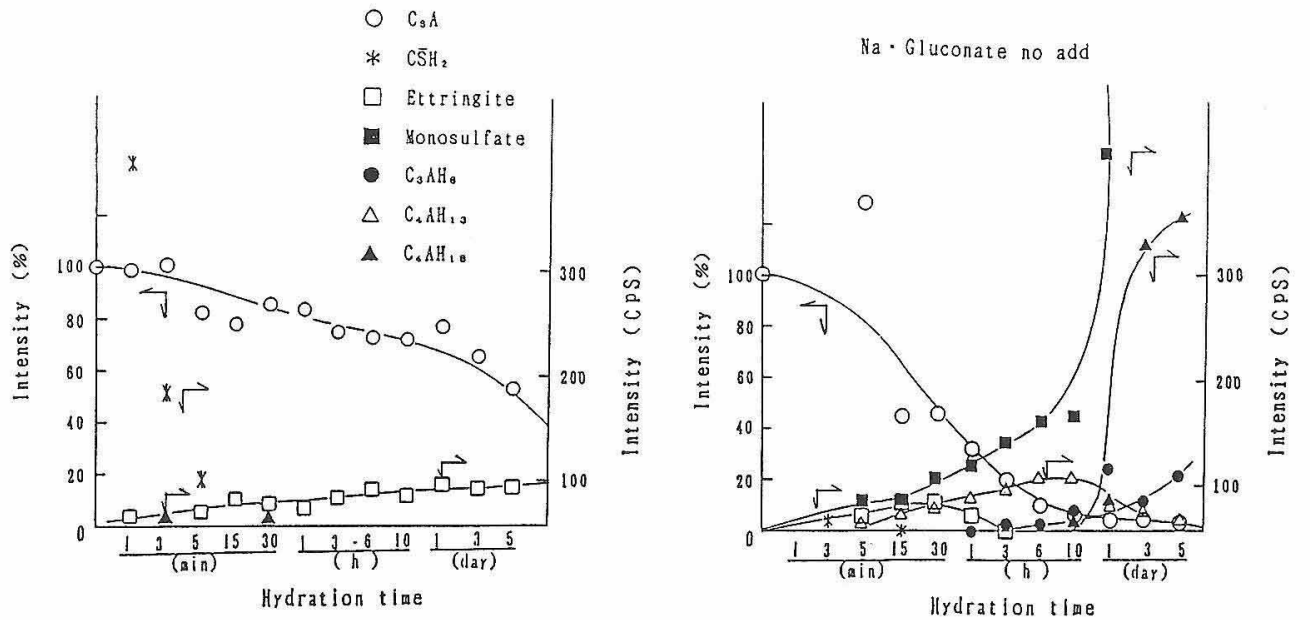

Fig. 10. The amounts of solid phase measured by XRD of $\mathrm{C}_{3} \mathrm{~A}-\mathrm{C} \overline{\mathrm{S}} \mathrm{H}_{2} 20 \mathrm{wt} \%-\mathrm{Na} \cdot \mathrm{Gluconate} 0.25 \mathrm{wt} \%$ system and without Gluconate system by various hydration time.

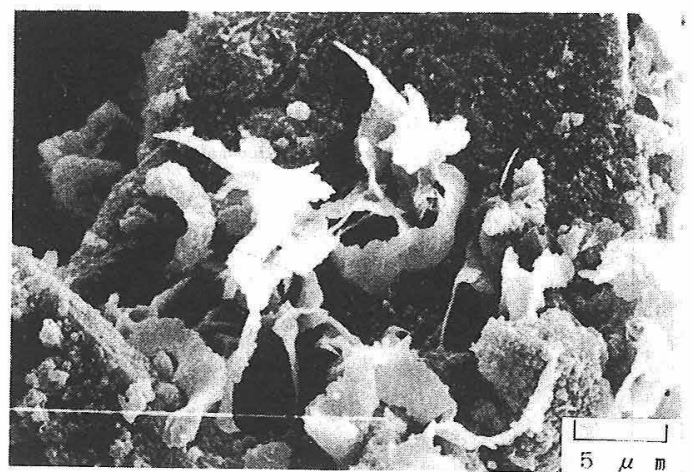

(1) 3 days

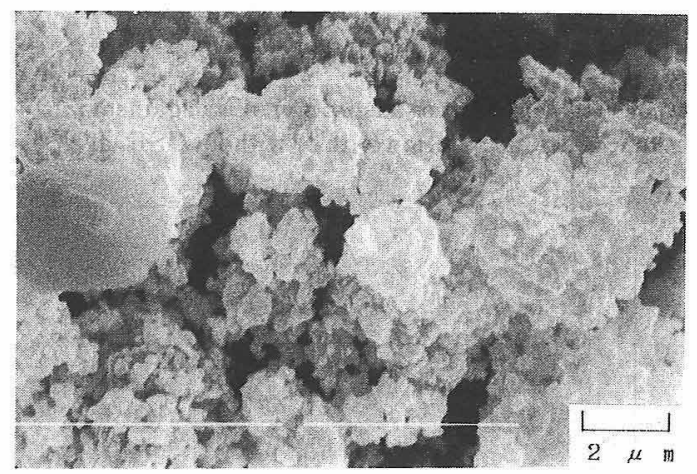

(2) 5 days

Fig. 11. SEM of solid phase of (1) $\mathrm{C}_{3} \mathrm{~A}-\mathrm{Na} \cdot \mathrm{Glu}$ conate $0.25 \mathrm{wt} \%$ system (2) $\mathrm{C}_{3} \mathrm{~A}-\mathrm{CSSH}_{2} 20 \mathrm{wt} \%$ $\mathrm{Na} \cdot$ Gluconate $0.25 \mathrm{wt} \%$ system.

変化を図 9 に, $\mathrm{CaSO}_{4} \cdot 2 \mathrm{H}_{2} \mathrm{O}$ が存在した図 4 に対応す るものを図 10 に示し，それぞれグルコン酸ナトリウム 添加の影響について比較した，また，このときの水和後 5 日に拈り SEM 写真を図 11 に示す。
$\mathrm{CaSO}_{4} \cdot 2 \mathrm{H}_{2} \mathrm{O}$ が共存しない試料（図 9 ) では, グル コン酸ナトリウムの添加により水和は無添加のときょり も著しく遅れ，水和 30 分以後で $\mathrm{C}_{3} \mathrm{AH}_{6}$ 水和物が認めら れる。また, $\mathrm{CaSO}_{4} \cdot 2 \mathrm{H}_{2} \mathrm{O}$ が共存した試料（図 10）で は,グルコン酸ナトリウムの添加により末水和 $\mathrm{C}_{3} \mathrm{~A} の$ XRD 強度は徐々に低下するが，エトリンガイトは水和 直後から生成している，エトリンガイトの生成はグルコ ン酸ナトリウム無添加のときでも水和直後から生成して おり，差異は認められない。グルコン酸ナトリウムを添 加すると， $\mathrm{C}_{3} \mathrm{~A}$ の消費が無添加のときよりも抑制され ており，生成するエトリンガイトのモノサルフェート $\left(3 \mathrm{CaO} \cdot \mathrm{Al}_{2} \mathrm{O}_{3} \cdot \mathrm{CaSO}_{4} \cdot 12 \mathrm{H}_{2} \mathrm{O}\right)$ への転化はまだ確恋さ れていない. 図11より，このときのエトリンガイトは 水和後 5 日にいたってもいわゆる針状を示さず, 粒状で あった。

\section{4. 考察}

（1）グルコン酸ナトリウムはアルカリ性の条件で $\mathrm{Ca}^{2+}$ 上 $\mathrm{Ca}$ 錯体を形成することが知られている4。 それ は高アルカリ性であればより安定である, 本実験でも $\mathrm{C}_{3} \mathrm{~A}$ から溶出される $\mathrm{Ca}^{2+}$ だでなく, $\mathrm{CaSO}_{4} \cdot 2 \mathrm{H}_{2} \mathrm{O}$ の $\mathrm{Ca}^{2+}$ とも $\mathrm{Ca}$ 錯体を形成すると考えることは妥当であ る. その構造式は次のように示される. これはグルコン
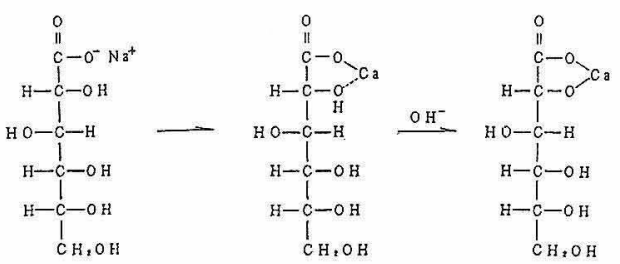

[ Na.Gluconate]

[ $\mathrm{Ca}-\cos$ ole $x$ ] 
酸カルシウムのような単なるカルシウム塩ではなく, 液 相中ではやや安定な 5 員環を形成しているものと考えら れる。

（2）図2, 図 3 に示した $\mathrm{C}_{3} \mathrm{~A}$-グルコン酸ナトリウ ム系では，グルコン酸ナトリウム濃度の高い方が液相中 に溶存する $\mathrm{Ca}$ 分の量が低下している。これは（1）で 述べたように，最初 $\mathrm{Ca}$ 錯体が形成されるが，水和の過 程で $\mathrm{C}_{3} \mathrm{~A}$ から $\mathrm{Ca}$ 分が溶出するに伴って共沈を引き起 こし，難溶性のゲル状物質を生じるからである。このよ うな現象は,

(1)上に述べたように，系内から多量の $\mathrm{Ca}$ 分が溶出 したり，あるいは，系外から $\mathrm{Ca}$ 分が加えられたと き,

(2) グルコン酸ナトリウムの濃度がより高いとき,

(3) 水和時間がより経過したとき, に急速に共沈を起こしやすい。そのため，グルコン酸ナ トリウムの濃度の高い方が液相中の $\mathrm{Ca}$ 分をより捕捉す るため，共沈後の Ca 分の濃度は低くなる．その結果， グルコン酸ナトリウムと $\mathrm{Ca}$ 分とによってグルコン酸カ ルシウムという単なる塩ではなく，無定形なものが末水 和粒子表面に被膜を形成する。したがって，末水和 $\mathrm{C}_{3} \mathrm{~A}$ は長い時間残存する。このような共沈の性質は $-\mathrm{COOH}$ 基, $>\mathrm{C}=\mathrm{O}$ 基， $-\mathrm{OH}$ 基を有するア二オン系界 面活性剂（例えば，グルタール酸，ピルビン酸など）に 多くみられ，グルコン酸ナトリウムに限らない。

(3) 図4, 図 5 に示した $\mathrm{C}_{3} \mathrm{~A}-\mathrm{CaSO}_{4} \cdot 2 \mathrm{H}_{2} \mathrm{O}-$ グルコ ン酸ナトリウム系の液相組成の経時変化をみると, これ は図 6 のグルコン酸ナトリウム無添加の場合と本質的に 変わるものではない。図6の Stage I では, 液相中の $\mathrm{Ca}$ 分, $\mathrm{SO}_{3}$ 分がエトリンガイトの生成のために急速に 消費される期間である。これは図 4 ，図 5 の Stage I に 相当する．ただし，グルコン酸ナトリウムの添加によっ て溶液中の濃度は高くなり，その期間が長くなる。すな わち, 水和直後から液相中の $\mathrm{Ca}$ 分, $\mathrm{SO}_{3}$ 分の量が増加 していく. $\mathrm{SO}_{3}$ 分の挙動をみると，グルコン酸ナトリ ウムの濃度が高いほど $\mathrm{CaSO}_{4} \cdot 2 \mathrm{H}_{2} \mathrm{O}$ の水に対する溶解 度 $1.02 \mathrm{~g} \mathrm{SO}_{3} / l$ 以上の值を示し, 高濃度を呈する時間 は長くなる。この原因は，（1）で述べた高アルカリ性 でグルコン酸ナトリウムが $\mathrm{Ca}^{2+}$ とやや安定な錯体を形 成するため, $\mathrm{CaSO}_{4} \cdot 2 \mathrm{H}_{2} \mathrm{O}$ の溶存量が増加し, その期 間が長時間持続するためである。

(4)エトリンガイトの生成は図 6 の Stage I が終 了してから観察されるのではなく，水和直後から観察さ れることに注意しなければならない。図10より，XRD では未反応 $\mathrm{CaSO}_{4} \cdot 2 \mathrm{H}_{2} \mathrm{O}$ が水和直後から急速に消隇し ている.図 4, 図 5 はこれと全く同様である.すなわち, Stage I の期間では液相中に $\mathrm{Ca}$ 分, $\mathrm{SO}_{3}$ 分が存在して いるにもかかわらず, 固相には未反応 $\mathrm{CaSO}_{4} \cdot 2 \mathrm{H}_{2} \mathrm{O}$ が
急速になくなる。この原因について著者らは既報 ${ }^{2)}$ で考 察したが, $\mathrm{CaSO}_{4} \cdot 2 \mathrm{H}_{2} \mathrm{O}$ が液相の飽和值を維持するた めに必要な量以外に, 過剩の $\mathrm{CaSO}_{4} \cdot 2 \mathrm{H}_{2} \mathrm{O}$ が存在して いるため, 後者のものが水和直後 $\mathrm{C}_{3} \mathrm{~A}$ と固液界面で急 速にトポケミカル反応を起こし, 極めて結晶性の悪い工 トリンガイトを生成することに起因している. 図 6 の場 合, Stage I の期間ではエトリンガイト，終了後はモノ サルフェートの生成が顕著に確認された。

（5）最も特徴的なのは Ca 分の挙動である. グルコ ン酸ナトリウム無添加の図 6 では, $\mathrm{CaSO}_{4} \cdot 2 \mathrm{H}_{2} \mathrm{O}$ が消 費された後, Stage II になり, 液相中の Ca 分の濃度が 上昇してくる.グルコン酸ナトリウムを添加すると水和 直後から液相中の Ca 分の濃度が上昇し, ピークが認め られる。これは $\mathrm{SO}_{3}$ 分の濃度と関連する。しかし, 図 4, 図 5 の Stage I が終了しないうちから, Ca 分は再 び上昇する.この後半のピークは $\mathrm{CaSO}_{4} \cdot 2 \mathrm{H}_{2} \mathrm{O}$ の消費 が不完全なまま，

$$
\begin{array}{r}
2 \mathrm{C}_{3} \mathrm{~A}+\mathrm{C}_{3} \mathrm{~A} \cdot 3 \mathrm{CaSO}_{4} \cdot 32 \mathrm{H}_{2} \mathrm{O}+4 \mathrm{H}_{2} \mathrm{O} \\
\longrightarrow 3\left(\mathrm{C}_{3} \mathrm{~A} \cdot \mathrm{CaSO}_{4} \cdot 12 \mathrm{H}_{2} \mathrm{O}\right)
\end{array}
$$

反応が開始され， $\mathrm{Ca}$ 分の濃度が上昇したもの上考えら れる。

（6）添加したグルコン酸ナトリウムは液相中で $\mathrm{Ca}$ 分と $\mathrm{Ca}$ 錯体を形成するが，（2）で述べたように共沈 を引き起こすので固相でも確認される，ただし，この場 合はグルコン酸ナトリウムの形では残らない。したがっ て，この上きに生成されるエトリンガイトの形状は針状 ではなく，少し丸みを帯びたものになる。図 7 より， $\mathrm{CaSO}_{4} \cdot 2 \mathrm{H}_{2} \mathrm{O}$ の有無にかかわらずグルコン酸は $\mathrm{C}_{3} \mathrm{~A} に$ 吸着されるが，その吸着量は $\mathrm{CaSO}_{4} \cdot 2 \mathrm{H}_{2} \mathrm{O}$ 共存の方が 少ない。すなわち, $\mathrm{CaSO}_{4} \cdot 2 \mathrm{H}_{2} \mathrm{O}$ が共存すると競争吸 着によりグルコン酸の吸着が抑制されることを示してい る.

（7）液相中の $\mathrm{Na}$ 分は反応に寄与することなく残存 すると考えられる。しかし，図８の吸着量をみるとその 一部は固相に吸着されている. $\mathrm{Na}$ 分がどのような形態 で吸着されているのかはわからない.ナフタレンスルホ ン酸塩のホルマリン高縮合物, リグニンスルホン酸塩な ぞの高性能減水剂を用いたときの吸着について, 深谷 ら ${ }^{5}$ は, $\mathrm{Na}^{+}$はカルシウムシリケート系鉱物の水和生成 物 CSH( I ) の固相に一部残存するが，エトリンガイト には吸着されないとしている。ただし，その形態につい ては明らかにしていない。本研究では, $\mathrm{Na}$ 分がエトリ ンガイトにも一部吸着されることを示しており，異なる 結果が得られた。

（8）図 1 より， $\mathrm{CaSO}_{4} \cdot 2 \mathrm{H}_{2} \mathrm{O}$ が共存しないときの 水和発熱速度をみると, グルコン酸ナトリウム添加に よって総発熱量は減少している。これは（2）で述べた ように, Ca 分上共沈を引き起こした結果, 未水和粒子 
表面に無定型のゲル状被膜を形成するからである。ただ し，グルコン酸ナトリウムは $\mathrm{C}_{3} \mathrm{~A}$ の水和反応を促進さ せたり, 遅延させたりすることはできない, 他方, $\mathrm{CaSO}_{4} \cdot 2 \mathrm{H}_{2} \mathrm{O}$ が共存したときをみると, 総発熱量はあ まり減少しない。これは（6）で述べたように， $\mathrm{CaSO}_{4} \cdot 2 \mathrm{H}_{2} \mathrm{O}$ がグルコン酸ナトリウムの吸着を抑える 作用をするからである.この場合も水和直後の 1 次発熱 にはあまり影響を与えない。しかし，図 1 では割愛した が, エトリンガイト生成に伴う 2 次発熱に影響し, これ が遅延した。

（9） ポルトランドセメントの水和初期の物性に多大 な影響を与えるものは, 著者は従来から接水直後の液相 の挙動にあると考察している. 表 1 より, 凝結の始発時 間がむしろ速まる原因とか, グルコン酸ナトリウム無添 加のときのポルトランドセメントの偽凝結の原因なども これとよく類似している. 後者の場合は練り混ぜ時間が 非常に短い場合に起こるといわれている ${ }^{6)}$.このような 現象は凝結時間だけでなく, セメントペーストの流動性 にも影響するものと考えられる. 名和ら”は, 高性能減 水剂を用いた研究で, 水和セメント粒子表面のら電位 を測定し, 液相中の $\mathrm{SO}_{4}{ }^{2-}$ の水和セメント粒子への吸 着が流動性に影響し, 硫酸アルカリや $\mathrm{CaSO}_{4} \cdot 2 \mathrm{H}_{2} \mathrm{O}$ 共 存下では水和初期の流動性が低下すると報告している。

このような現象が起こる原因の解明はまだ不十分では あるが, 本研究より, Stage I の期間で液相中の Ca 分 の濃度が飛躍し, その後, 低下するといった水和直後の 非常に速い溶解, 析出現象が起こっていることに関係す ると考えられる. 図 4, 図 5 に示した Ca 分の初期のピー クはこれに相当するものである.

\section{5. 総 括}

アニオン系界面活性剤を添加したときのポルトランド セメントの凝結の始発時間は, プレーンのときよりもむ
しろ速まることが起こる.このような現象はエトリンガ イト生成時における有機混和剤の作用に起因すると考え られる.この原因は接水直後の液相の挙動にあると考え, 本研究では, グルコン酸ナトリウムが存在したときの工 トリンガイトの生成過程を検討した. 結果は次のように 要約される.

(1) $\mathrm{CaSO}_{4} \cdot 2 \mathrm{H}_{2} \mathrm{O}$ が共存した $\mathrm{C}_{3} \mathrm{~A}$ の水和では, 液 相中の $\mathrm{Ca}$ 分, $\mathrm{SO}_{3}$ 分がエトリンガイトの生成のために 急速に消費される. これにグルコン酸ナトリウムを添加 した場合は溶液中の濃度は高くなり, 高濃度を呈する時 間は長くなる。

（2）この原因は，高アルカリ性でグルコン酸ナトリ ウムが $\mathrm{Ca}^{2+}$ とやや安定な錯体を形成するため, $\mathrm{CaSO}_{4}$ $\cdot 2 \mathrm{H}_{2} \mathrm{O}$ の溶解度が増加し, その期間が長時間持続する ためである。

（3）エトリンガイトは水和直後から急速に生成され る.この期間における未反応 $\mathrm{CaSO}_{4} \cdot 2 \mathrm{H}_{2} \mathrm{O}$ は急速に消 費される.

（4）グルコン酸ナトリウムを添加すると水和直後に 液相中の $\mathrm{Ca}$ 分の濃度が上昇し, その後, 低下するといっ た非常に速い溶解, 析出現象が起こる.

(5) $\mathrm{CaSO}_{4} \cdot 2 \mathrm{H}_{2} \mathrm{O}$ が共存すると競争吸着によりグ ルコン酸の $\mathrm{C}_{3} \mathrm{~A}$ への吸着が抑制される.

\section{文 献}

1) F.W. Locher, W. Richartz and S. Sprung, ZementKalk-Gips, 29, 435-42 (1976).

2）露木尚光, 廣田紀昭, 宮川継男, 笠井順一, 窯協, 92, 554-61 (1984).

3) J.F. Young, Cement and Concrete Research, 2, 415-33 (1972).

4）坂口武一, 上野景平, “金属キレート III”, 南江堂 (1970) pp. 107-08.

5) Y. Fukaya and K. Kato, 8th International Congress on the Chemistry of Cement, 3, 142-47 (1986).

6) F. W. Locher, Zement-Kalk-Gips, 26, 53-62 (1973).

7）名和豊春, 江口 仁, セメント技術年報, 41, 46-49(1987). 